\title{
Hepatitis C virus-specific cellular immune responses in individuals with no evidence of infection
}

\author{
Yves Rivière ${ }^{1 *}$, Thomas Montange ${ }^{1}$, Geneviève Janvier ${ }^{1}$, Caroline Marnata ${ }^{1}$, Ludovic Durrieu ${ }^{1}$, Marie-Laure Chaix ${ }^{2}$, \\ Maria Isaguliants ${ }^{3}$, Odile Launay ${ }^{4}$, Jean-Louis Bresson ${ }^{5}$ and Stanislas Pol ${ }^{6}$
}

\begin{abstract}
The detection of hepatitis C virus (HCV)-specific T cell responses in HCV-uninfected, presumably unexposed, subjects could be due to an underestimation of the frequency of spontaneously resolving infections, as most acute HCV infections are clinically silent. To address this hypothesis, HCV-specific cellular immune responses were characterized, in individuals negative for an HCV PCR assay and humoral response, with $(n=32)$ or without $(n=$ 33) risk of exposure to HCV. Uninfected volunteers $(n=20)$ with a chronically HCV-infected partner were included as positive controls for potential exposure to HCV and HCV infection, respectively. HCV-specific T cell responses in freshly isolated peripheral blood mononuclear cells were studied ex vivo by ELISPOT and CFSE-based proliferation assays using panels of HCV Core and NS3-derived peptides. A pool of unrelated peptides was used as a negative control, and a peptide mix of human cytomegalovirus, Epstein-Bar virus and Influenza virus as a positive control. Overall, $20 \%$ of presumably HCV-uninfected subject tested had detectable T-cell responses to the virus, a rate much higher than previous estimates of HCV prevalence in developed countries. This result would be consistent with unapparent primary HCV infections that either cleared spontaneously or remained undetected by conventional serological assays.
\end{abstract}

Keywords: HCV, Prevalence, Proliferation, Elispot, Inapparent infection

\section{Background}

Hepatitis $\mathrm{C}$ virus $(\mathrm{HCV})$ is a positive stranded RNA virus belonging to the Flavivirida family. HCV replicates mainly in the liver, and approximately $70 \%$ of infected persons fail to spontaneously clear the virus, progressing to chronic infection. HCV infection is defined as the detection of specific antibodies in the serum (by two different screening assays), with or without detectable HCV-specific RNA which reflects ongoing or resolved infection, respectively. An estimated 170 million persons worldwide are infected by HCV.

Three sets of data challenge current estimates of the proportion of $\mathrm{HCV}$-infected patients that become chronic carriers [1]. Firstly, HCV-specific T lymphocytes are found in the blood of donors who do not meet

\footnotetext{
* Correspondence: yves.riviere@pasteur.fr

'Laboratoire d'Immunopathologie Virale, Institut Pasteur; and CNRS URA

3015, 25 rue du Dr Roux, 75015 Paris, France

Full list of author information is available at the end of the article
}

current criteria for HCV infection, displaying a weak or restricted specific antibody response labeled as an 'indeterminate pattern' in the recombinant immunoblot confirmation assay [2]. Secondly, the clearance of HCV has been reported in individuals without detectable seroconversion [3]. Thirdly, the disappearance of circulating antiHCV antibodies some two decades after an accidental inoculation has been documented in patients who spontaneously resolve their infection, although $\mathrm{HCV}$-specific $\mathrm{CD}^{+}$and $\mathrm{CD} 8^{+} \mathrm{T}$-cell responses were detectable [4].

Thus, as most acute HCV infections are clinically silent, the detection of a virus-specific $\mathrm{T}$ cell response in healthy presumably unexposed subjects who do not meet current criteria for a previous HCV infection can be due to preceding silent spontaneously resolved $\mathrm{HCV}$ infection, the frequency of which is apparently underestimated $[5,6]$. Viral infection in such individuals would have produced enough viral immunogen to prime $T$ cells, but yet not enough to prime an IgG B cell response that could 
be detected by the available commercial assays [3,7]. If confirmed, such an hypothesis could change our views concerning the epidemiology and physiopathology of $\mathrm{HCV}$ infections. An alternative hypothesis could be the existence of $\mathrm{T}$ cell epitope cross-reactivity between other pathogens or common antigens present in the general population and HCV as previously reported [8-10]. These two hypotheses are not mutually exclusive.

To investigate such possibilities, HCV-specific cellular immune responses were characterized in uninfected individuals (UI) where neither the presence of $\mathrm{HCV}$ RNA nor that of anti-HCV antibody had previously been detected. Exposed uninfected volunteers (EUI) and their chronically $\mathrm{HCV}$-infected (CI) sexual partners were included in this study as positive controls for HCV exposure and infection, respectively.

\section{Results}

We assembled three cohorts of individuals that differed in their history with respect to potential exposure to $\mathrm{HCV}$, and HCV infection. The first group comprised apparently noninfected, nonexposed volunteers (UI), although about half of these were at risk of exposure to the virus. Exclusion factors for exposure to HCV [11] were: professional exposure, drug abuse, blood transfusion or injection of blood products, sexually transmitted diseases, incarceration, alcoholism, dialysis, endoscopy, acupuncture, mesotherapy, invasive cosmetic treatment, piercing, tattooing, sexual exposure, familial exposure, and hospitalization or outpatient treatment in a developing country. A second group consisted of individuals who remained uninfected despite repeated exposure (EUI), who were in fact exposed through their sexual contact with a member of the third group: their long-standing chronically-infected $(\mathrm{CI})$ partners.

\section{HCV-specific responses}

Proliferative responses

$\mathrm{HCV}$-specific proliferative $\mathrm{T}$ cell responses were tested in 62 of the 65 uninfected volunteers (UI). Among these, 2 were positive for Core, and 4 for NS3 (Table 1). The response directed against Core involved both CD4 and CD8 populations for volunteer EFS20 who had no known risk of $\mathrm{HCV}$ exposure (Figure 1, panels A \& B, and Table 2), and a CD4 population for EFS 11 (at risk) (Table 3). For NS3, a response involved the CD4 population (COC 13, Table 2, and EFS14, Table 3), the CD8 population (EFS 21, Table 3) or both CD4 and CD8 populations (EFS 24, Table 3). All three EFS donors were at risk of $\mathrm{HCV}$ exposure, in contrast to risk-free volunteer $\mathrm{COC} 13$. None of the supposedly uninfected (UI) volunteers was found to be positive for both NS3 and Core.

In the group of chronically infected patients (CI) 17 patients were tested (Table 1), and three showed a Core-specific response: one (CIC 34) involving the CD8 population and two $(\mathrm{CIC} 38,46)$ the $\mathrm{CD} 4$ population (Table 4, and Figure 2, panel A). For NS3, 2/16 patients were positive: one involving CD8 cells (CIC18), and one CD4 (CIC 38) (Table 4, and Figure 2 panel C). Thus one patient (CIC 38) was positive for both NS3 and Core, in both cases the response involving the CD4 population.

None of the 17 exposed but uninfected (EUI) volunteers was positive for either Core or NS3 (Table 1).

No statistical difference was found in the frequencies of proliferative responses to both $\mathrm{HCV}$ antigens in pairwise comparisons of all groups ( $t$-test for independent samples; all $p$ 's > 0.05) (Table 1).

\section{Elispot responses}

The same antigens were used in Elispot assays to assess the occurrence/frequency of $\mathrm{HCV}$-specific circulating effector T lymphocyte responses. Eight of 65 uninfected (UI) volunteers tested were positive for Core, and none for NS3 (Table 1). Four of the 8 volunteers that gave a positive Core response were at risk (CIC 05, 22, 55, 59; Table 3), and 4 were without any known risk for $\mathrm{HCV}$ exposure (CIC 16 and 17, COC 17, and EFS 20; Table 2 ). This last donor was also positive in the proliferation test (see above).

Table 1 Proliferative and Elispot responses in chronically HCV-infected, exposed and uninfected volunteers

\begin{tabular}{|c|c|c|c|c|c|c|c|}
\hline & & \multicolumn{3}{|c|}{ PROLIFERATION } & \multicolumn{3}{|c|}{ ELISPOT } \\
\hline \multicolumn{2}{|c|}{ VOLUNTEERS } & CORE & NS3 & CEF & CORE & NS3 & CEF \\
\hline & All & $2 / 61(3)^{4}$ & $4 / 62(6)$ & $24 / 62$ (39) & $8 / 65(12)$ & $0 / 59(0)$ & $31 / 58(53)$ \\
\hline \multirow[t]{2}{*}{$\mathrm{UI}^{1}$} & No risk & $1 / 29(3)$ & $1 / 30(3)$ & $10 / 30(33)$ & $4 / 33(12)$ & $0 / 29(0)$ & $13 / 28(46)$ \\
\hline & At risk & $1 / 32(3)$ & $3 / 32(9)$ & $14 / 32(44)$ & $4 / 32(13)$ & $0 / 30(0)$ & $18 / 30(60)$ \\
\hline \multicolumn{2}{|c|}{$\mathrm{EUI}^{2}$} & $0 / 17(0)$ & $0 / 17(0)$ & $5 / 17(29)$ & $6 / 20(30)$ & 1/11 (9) & $6 / 11(55)$ \\
\hline \multicolumn{2}{|c|}{$\mathrm{Cl}^{3}$} & $3 / 17$ (18) & $2 / 16(12,5)$ & $9 / 16(56)$ & $8 / 20(40)$ & $2 / 6(33)$ & $3 / 6(50)$ \\
\hline
\end{tabular}

1: Uninfected individuals (UI); 2: Exposed uninfected partners (EUI) of, 3: chronically HCV-infected (CI) individuals. 4: number positive/total number tested (percent). Control antigen (CEF) : There were no statistical difference in the frequencies of proliferative or elispot responses to CEF when comparing each group 2 by 2 . HCV antigens : There were no statistical difference in the frequencies of proliferative response to both Core and NS3 when comparing each group 2 by 2 ; The frequencies of Elispot response to Core were higher in the $\mathrm{Cl}$ group compared to $\mathrm{UI}$ no risk $(p=0.04)$ and to UI at risk $(p=0.04)$. The frequencies of Elispot response to NS3 were higher in the $\mathrm{Cl}$ group compared to $\mathrm{UI}$ no risk $(p<0.03)$ and to $\mathrm{UI}$ at risk $(p<0.03)$. 


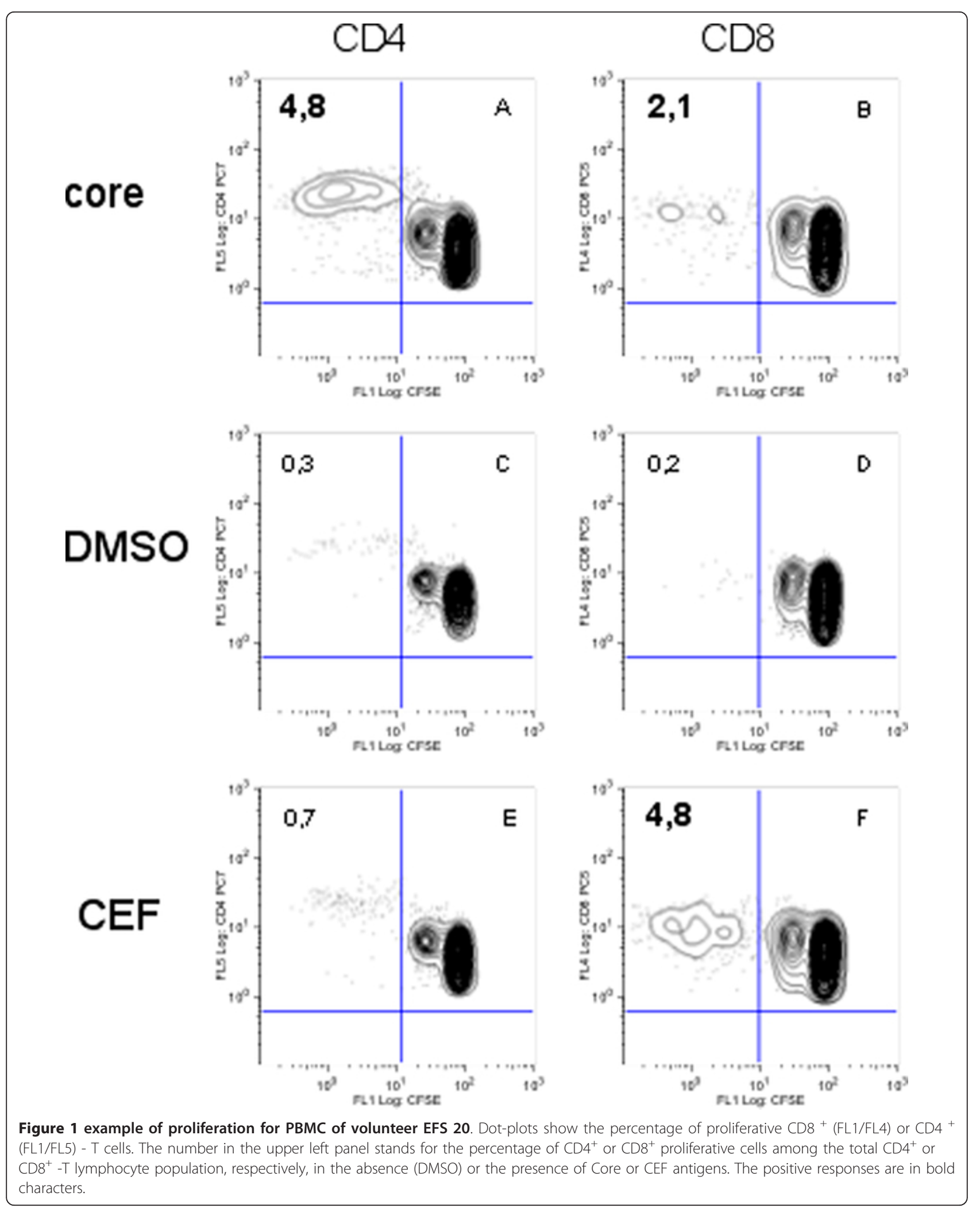


Table 2 Responses in uninfected volunteers with no known risk of exposure to HCV

\begin{tabular}{|c|c|c|c|c|c|c|c|}
\hline \multirow[t]{2}{*}{ I.D } & \multirow[t]{2}{*}{ Sex } & \multicolumn{3}{|c|}{ Proliferation* } & \multicolumn{3}{|c|}{ Elispot** } \\
\hline & & Core & NS3 & CEF & Core & NS3 & CEF \\
\hline CIC 09 & $\mathrm{~F}$ & $(-)$ & $(-)$ & $(-)$ & $(-)$ & $(-)$ & 15 \\
\hline CIC 16 & M & $(-)$ & $(-)$ & $(-)$ & 24 & bgd & bgd \\
\hline CIC 17 & M & ND & ND & ND & 9 & ND & ND \\
\hline CIC 23 & M & ND & ND & ND & $(-)$ & ND & ND \\
\hline CIC 53 & $M$ & $(-)$ & $(-)$ & $(-)$ & $(-)$ & $(-)$ & $(-)$ \\
\hline EFS 04 & $\mathrm{~F}$ & $(-)$ & $(-)$ & $6(\mathrm{~T} 8)$ & $(-)$ & $(-)$ & 252 \\
\hline EFS 05 & $\mathrm{~F}$ & $(-)$ & $(-)$ & $(-)$ & $(-)$ & $(-)$ & $(-)$ \\
\hline EFS 08 & $\mathrm{~F}$ & bgd & bgd & bgd & $(-)$ & $(-)$ & $(-)$ \\
\hline EFS 10 & $\mathrm{~F}$ & $(-)$ & $(-)$ & 7 (T8) & $(-)$ & $(-)$ & $(-)$ \\
\hline EFS 16 & M & $(-)$ & $(-)$ & bgd & $(-)$ & $(-)$ & 17 \\
\hline EFS 18 & $\mathrm{~F}$ & $(-)$ & $(-)$ & $(-)$ & $(-)$ & $(-)$ & $(-)$ \\
\hline EFS 20 & $\mathrm{~F}$ & 9 (T8), 16(T4) & $(-)$ & 19 (T8) & 18 & $(-)$ & 9 \\
\hline EFS 22 & $\mathrm{~F}$ & $(-)$ & $(-)$ & $(-)$ & $(-)$ & $(-)$ & 8 \\
\hline COC 01 & M & ND & ND & ND & $(-)$ & $(-)$ & ND \\
\hline COC 02 & $\mathrm{~F}$ & $(-)$ & $(-)$ & $(-)$ & $(-)$ & $(-)$ & $(-)$ \\
\hline $\operatorname{COC} 03$ & $\mathrm{~F}$ & $(-)$ & $(-)$ & $(-)$ & $(-)$ & ND & ND \\
\hline $\operatorname{COC} 04$ & $M$ & $(-)$ & $(-)$ & 14 (T8) & $(-)$ & $(-)$ & 9 \\
\hline COC 05 & M & $(-)$ & $(-)$ & $(-)$ & $(-)$ & $(-)$ & $(-)$ \\
\hline $\operatorname{coc} 06$ & $M$ & $(-)$ & $(-)$ & $(-)$ & $(-)$ & $(-)$ & 16 \\
\hline $\mathrm{COC} 07$ & $M$ & $(-)$, bgd & $(-)$, bgd & 20 (T8) & $(-)$ & $(-)$ & 20 \\
\hline $\mathrm{COC} 08$ & $\mathrm{~F}$ & $(-)$ & $(-)$ & 5 (T8) & $(-)$ & $(-)$ & $(-)$ \\
\hline COC 09 & $\mathrm{~F}$ & $(-)$, bgd & $(-), \mathrm{bgd}$ & 16 (T8) & $(-)$ & $(-)$ & 24 \\
\hline $\operatorname{COC} 10$ & M & $(-)$ & $(-), \mathrm{bgd}$ & $(-)$ & $(-)$ & $(-)$ & 34 \\
\hline COC 11 & M & $(-)$ & $(-)$ & $(-)$ & $(-)$ & $(-)$ & $(-)$ \\
\hline $\operatorname{COC} 12$ & $\mathrm{~F}$ & $(-)$ & $(-), \mathrm{bgd}$ & $(-)$ & $(-)$ & $(-)$ & $(-)$ \\
\hline $\operatorname{COC} 13$ & $\mathrm{~F}$ & $(-)$ & 7 (T4) & 16 (T8) & $(-)$ & $(-)$ & 13 \\
\hline $\operatorname{COC} 14$ & M & $(-)$ & $(-)$ & $(-)$ & $(-)$ & $(-)$ & $(-)$ \\
\hline $\operatorname{COC} 15$ & $\mathrm{~F}$ & $(-)$ & $(-)$ & $(-)$ & $(-)$ & $(-)$ & $(-)$ \\
\hline $\operatorname{COC} 16$ & M & ND & $(-)$ & $(-)$ & $(-)$ & ND & ND \\
\hline COC 17 & M & $(-), \mathrm{bgd}$ & $(-)$, bgd & 14 (T8), bgd & 6 & $(-)$ & 5 \\
\hline $\operatorname{COC} 18$ & $\mathrm{~F}$ & $(-), \mathrm{bgd}$ & $(-)$, bgd & $(-)$ & $(-)$ & $(-)$ & $(-)$ \\
\hline COC 19 & M & $(-)$ & $(-)$ & $(-)$ & $(-)$ & $(-)$ & 1087 \\
\hline $\operatorname{coc} 20$ & $M$ & $(-)$ & $(-)$ & $5(\mathrm{~T} 8)$ & $(-)$ & $(-)$ & $(-)$ \\
\hline
\end{tabular}

* $(-)$ = absence, or $x x=$ presence of antigen-specific proliferation. (T4) or (T8) stands for the nature of the proliferating lymphocyte population, and the number for specific antigen to control antigen ratio. The CEF panel of EBV CMV and Flu peptides is described in ref 12 .

** $(-)=$ no antigen specific ELISPOT; $x x=$ presence of antigen specific ELISPOT response. The number stands for specific antigen to control ratio.

Abbreviations: bgd background level in absence of antigen; ND not determined.

All 20 chronically-infected (CI) subjects were tested for IFN- $\gamma$ production in response to Core, and six for IFN- $\gamma$ production in response to NS3 (Table 1). Eight presented a Core-specific response (CIC 2, 18, 25, 31$32,40,46,64)$ and two NS3-specific IFN- $\gamma$ response (CIC 18 and 40). Thus 2 individuals (CIC 18 and 40)
Table 3 Responses in uninfected volunteers at risk for exposure to HCV

\begin{tabular}{|c|c|c|c|c|c|c|c|}
\hline \multirow[t]{2}{*}{ I.D } & \multirow[t]{2}{*}{ Sex } & \multicolumn{3}{|c|}{ Proliferation* } & \multicolumn{3}{|c|}{ Elispot** } \\
\hline & & Core & NS3 & CEF & Core & NS3 & CEF \\
\hline $\mathrm{CIC} 03$ & $\mathrm{~F}$ & $(-), \mathrm{bgd}$ & $(-), \mathrm{bgd}$ & $(-)$, bgd & $(-)$ & $(-)$ & 38 \\
\hline CIC 04 & $\mathrm{~F}$ & $(-)$ & $(-)$ & $5(\mathrm{~T} 8)$ & $(-)$ & $(-)$ & $(-)$ \\
\hline CIC 05 & $\mathrm{~F}$ & $(-)$, bgd & $(-)$, bgd & 43(T8), bgd & 25 & $(-)$ & 572 \\
\hline$\overline{\mathrm{CIC}} 06$ & $\mathrm{~F}$ & $(-)$ & $(-)$ & $(-)$ & $(-)$ & $(-)$ & $(-)$ \\
\hline CIC 07 & $M$ & $(-)$, bgd & $(-)$, bgd & $(-)$, bgd & $(-)$ & $(-)$ & $(-)$ \\
\hline$\overline{\mathrm{CIC}} 08$ & $\mathrm{~F}$ & $(-)$ & $(-)$ & 47(T8) & $(-)$ & $(-)$ & 47 \\
\hline CIC 20 & $M$ & bgd & bgd & bgd & $(-)$ & $(-)$ & $(-)$ \\
\hline CIC 22 & $M$ & $(-)$ & $(-)$ & 18 (T8) & 344 & $\mathrm{ND}$ & $\mathrm{ND}$ \\
\hline CIC 50 & $M$ & $(-)$ & $(-)$ & $(-)$ & $(-)$ & $(-)$ & $(-)$ \\
\hline CIC 54 & $\mathrm{~F}$ & $(-)$ & $(-)$ & $306($ (T8) & $(-)$ & $(-)$ & $(-)$ \\
\hline CIC 55 & $M$ & $(-)$ & $(-)$ & $(-)$ & 27 & $(-)$ & 10 \\
\hline CIC 58 & $\mathrm{~F}$ & $(-)$ & $(-)$ & $(-)$ & $(-)$ & $(-)$ & $(-)$ \\
\hline CIC 59 & $M$ & $(-)$ & $(-)$ & $(-)$ & 39 & $N D$ & $\mathrm{ND}$ \\
\hline CIC 62 & $\mathrm{~F}$ & $(-)$ & $(-)$ & $(-)$ & $(-)$ & $(-)$ & 429 \\
\hline CIC 63 & $\mathrm{~F}$ & $(-)$ & $(-)$ & $(-)$ & $(-)$ & $(-)$ & 13 \\
\hline EFS 01 & $\mathrm{~F}$ & $(-)$ & $(-)$ & $(-)$ & $(-)$ & $(-)$ & 33 \\
\hline EFS 02 & $M$ & $(-)$ & $(-)$ & $(-)$ & $(-)$ & $(-)$ & 7 \\
\hline EFS 03 & $\mathrm{~F}$ & $(-)$ & $(-)$ & $(-)$ & $(-)$ & $(-)$ & $(-)$ \\
\hline EFS 06 & $\mathrm{~F}$ & $(-)$ & $(-)$ & 120(T8) & $(-)$ & $(-)$ & 44 \\
\hline EFS 07 & $\mathrm{~F}$ & $(-)$ & $(-)$ & $(-)$ & $(-)$ & $(-)$ & $(-)$ \\
\hline EFS 09 & $\mathrm{~F}$ & $(-)$ & $(-)$ & $8($ (T8) & $(-)$ & $(-)$ & 6 \\
\hline EFS 11 & $\mathrm{~F}$ & 7(T4) & $(-)$ & $5(\mathrm{~T} 8)$ & $(-)$ & $(-)$ & 29 \\
\hline EFS 12 & $\mathrm{~F}$ & $(-)$ & $(-)$ & 110(T8),11(T4) & $(-)$ & bgd & $\mathrm{bgd}$ \\
\hline EFS 13 & $\mathrm{~F}$ & $(-)$ & $(-)$ & $(-)$ & $(-)$ & $(-)$ & $(-)$ \\
\hline EFS 14 & $F$ & $(-)$ & $10(T 4)$ & $8($ (T8) & $(-)$ & $(-)$ & 178 \\
\hline EFS 15 & $\mathrm{~F}$ & $(-)$ & $(-)$ & $(-)$ & $(-)$ & $(-)$ & 28 \\
\hline EFS 17 & $F$ & $(-)$ & $(-)$ & $5(\mathrm{~T} 8)$ & $(-)$ & $(-)$ & 63 \\
\hline EFS 19 & $M$ & $(-)$ & $(-)$ & 15(T8) & $(-)$ & $(-)$ & 76 \\
\hline EFS 21 & $F$ & $(-)$ & 7(T8) & 21 (T8) & $(-)$ & $(-)$ & $(-)$ \\
\hline EFS 23 & $\mathrm{~F}$ & $(-)$, bgd & $(-)$, bgd & $(-)$, bgd & $(-)$ & $(-)$ & 7 \\
\hline EFS 24 & $F$ & $(-)$ & $6(\mathrm{~T} 8), 7(\mathrm{~T} 4)$ & 9(T8) & $(-)$ & $(-)$ & 20 \\
\hline EFS 25 & $F$ & $(-)$ & $(-)$ & $(-)$ & $(-)$ & $(-)$ & 32 \\
\hline
\end{tabular}

* $(-)=$ absence, or $x x=$ presence of antigen-specific proliferation. (T4) or (T8) stands for the nature of the proliferating lymphocyte population, and the number for specific antigen to control antigen ratio. The CEF panel of EBV, CMV and Flu peptides is described in ref 12 .

** $(-)=$ no antigen specific ELISPOT; $x x=$ presence of antigen specific ELISPOT response. The number stands for specific antigen to control ratio.

Abbreviations: bgd background level in absence of antigen; ND not determined.

demonstrated IFN- $\gamma$ production in response to both viral proteins tested (Tables 1 and 4).

Six of 20 exposed but uninfected (EUI) partners demonstrated IFN- $\gamma$ production in response to Core (CIC 24, 28, 30, 37, 41 and 45), and 1 of 11 tested an IFN- $\gamma$ response to NS3 (CIC 43); none responded to both viral antigens (Tables 1 and 4 ). 
Table 4 Characteristics of the $\mathbf{2 0}$ pairs of chronically HVC infected patients and their exposed uninfected partners

\begin{tabular}{|c|c|c|c|c|c|c|c|c|c|c|c|c|}
\hline \multicolumn{2}{|c|}{ I.D* } & \multirow[t]{2}{*}{ Sex } & \multicolumn{4}{|c|}{ HCV infection $* *$} & \multicolumn{3}{|c|}{ Proliferation $* * *$} & \multicolumn{3}{|c|}{ Elispot ${ }^{* * * *}$} \\
\hline & & & Viral load & Genotype & Duration & Mode & Core & NS3 & CEF & Core & NS3 & CEF \\
\hline $\mathrm{Cl}$ & $\mathrm{ClC} 02$ & $\mathrm{~F}$ & 354000 & $1 b$ & 22 & Blood T & $(-)$ & $(-)$ & $143($ (T) & 10 & $\mathrm{ND}$ & ND \\
\hline EUI & $\mathrm{CIC} 01$ & M & - & - & - & - & $(-)$, bgd & $(-)$, bdg & 10(T8), bgd & $(-)$ & $(-)$ & 4 \\
\hline $\mathrm{Cl}$ & $\mathrm{CIC} 10$ & $\mathrm{~F}$ & 20000 & 4 & ND & Unknown & $(-)$ & $(-)$ & 18(T8) & $(-)$ & $(-)$ & 6 \\
\hline EUI & CIC 11 & M & - & - & - & - & ND & ND & ND & $(-)$ & bgd & bgd \\
\hline $\mathrm{Cl}$ & $\mathrm{CIC} 12$ & $\mathrm{~F}$ & 210000 & $4 \mathrm{c} / \mathrm{b}$ & 15 & Surgery & bgd & bgd & bgd & $(-)$ & ND & ND \\
\hline EUI & CIC 13 & M & - & - & - & - & $(-)$, bgd & $(-)$, bgd & 5(T8), bgd & $(-)$ & $(-)$ & 16 \\
\hline $\mathrm{Cl}$ & CIC 14 & $\mathrm{~F}$ & 1850000 & $1 \mathrm{a}$ & 24 & IVDU & $(-)$ & $(-)$ & 11(T8) & $(-)$ & $\mathrm{ND}$ & ND \\
\hline EUI & $\mathrm{CIC} 15$ & M & - & - & & & ND & ND & ND & $(-)$ & $(-)$ & 13 \\
\hline $\mathrm{Cl}$ & $\mathrm{CIC} 18$ & $\mathrm{~F}$ & 380000 & 3 & 24 & IVDU & $(-)$ & 76 (T8) & $(-)$ & 21 & 295 & $(-)$ \\
\hline EUI & CIC 19 & M & - & - & - & - & $(-)$ & $(-)$ & $(-)$ & $(-)$ & $(-)$ & $(-)$ \\
\hline $\mathrm{Cl}$ & ClC 25 & $M$ & 1300000 & $1 b$ & 23 & tattooing & $(-)$ & ND & $\mathrm{ND}$ & 4 & $\mathrm{ND}$ & ND \\
\hline EUI & CIC 24 & $\mathrm{~F}$ & - & - & - & - & $(-)$ & $(-)$ & 83(T8) & 12 & ND & ND \\
\hline $\mathrm{Cl}$ & CIC 26 & M & 215000 & $1 b$ & 16 & Blood T & $(-)$ & $(-)$ & $11(\mathrm{~T} 8)$ & $(-)$ & $N D$ & ND \\
\hline EUI & CIC 27 & $\mathrm{~F}$ & - & - & - & - & $(-)$, bgd & $(-)$, bgd & $(-)$, bgd & $(-)$ & $\mathrm{ND}$ & ND \\
\hline $\mathrm{Cl}$ & CIC 29 & $F$ & 30000 & ND & ND & Unknown & bgd & bgd & bgd & $(-)$ & $(-)$ & $(-)$ \\
\hline EUI & CIC 28 & M & - & - & - & - & $(-)$ & $(-)$ & 37(T8) & 7 & bgd & bgd \\
\hline $\mathrm{Cl}$ & CIC 31 & M & 200000 & $1 b$ & 37 & Blood T & ND & ND & ND & 8 & $N D$ & ND \\
\hline EUI & $\mathrm{CIC} 30$ & $\mathrm{~F}$ & - & - & - & - & $(-)$ & $(-)$ & 9(Т8) & 55 & $(-)$ & 45 \\
\hline $\mathrm{Cl}$ & $\mathrm{CIC} 32$ & $M$ & 1425000 & $1 b$ & ND & Unknown & $(-)$ & $(-)$ & $(-)$ & 10 & $N D$ & ND \\
\hline EUI & $\mathrm{CIC} 33$ & $\mathrm{~F}$ & - & - & - & - & $(-)$ & $(-)$ & $(-)$ & $(-)$ & ND & ND \\
\hline $\mathrm{Cl}$ & $\mathrm{ClC} 34$ & $M$ & 100000 & $1 \mathrm{~b}$ & 16 & Blood T & $14(T 8)$ & $(-)$ & $(-)$ & $(-)$ & $N D$ & ND \\
\hline EUI & $\mathrm{CIC} 35$ & $\mathrm{~F}$ & - & - & - & - & $(-)$ & $(-)$ & $(-)$ & $(-)$ & $(-)$ & 89 \\
\hline $\mathrm{Cl}$ & CIC 36 & $F$ & 35000 & $3 a$ & ND & Unknown & $(-)$ & $(-)$ & 29(T8) & $(-)$ & ND & ND \\
\hline EUI & $\mathrm{CIC} 37$ & M & - & - & - & - & $(-)$ & $(-)$ & $(-)$ & 12 & $(-)$ & 72 \\
\hline $\mathrm{Cl}$ & $\mathrm{ClC} 38$ & $F$ & 260000 & $1 a$ & 43 & Blood T & 7(T4) & 4(T4) & 433(Т8) & $(-)$ & $N D$ & ND \\
\hline EUI & CIC 39 & M & - & - & - & - & $(-)$ & $(-)$ & $(-)$ & $(-)$ & ND & ND \\
\hline $\mathrm{Cl}$ & $\mathrm{ClC} 40$ & $M$ & 332000 & $1 \mathrm{a}$ & 16 & Blood T & $(-)$ & $(-)$ & 10(T8) & 19 & 8 & 100 \\
\hline EUI & CIC 41 & $\mathrm{~F}$ & - & - & - & - & $(-)$ & $(-)$ & $(-)$ & 10 & ND & ND \\
\hline $\mathrm{Cl}$ & $\mathrm{CIC} 42$ & $F$ & 140000 & $1 b$ & 20 & Blood T & $(-)$ & $(-)$ & $(-)$ & $(-)$ & $(-)$ & $(-)$ \\
\hline EUI & $\mathrm{CIC} 43$ & M & - & - & - & - & $(-)$ & $(-)$ & $(-)$ & $(-)$ & 7 & $(-)$ \\
\hline $\mathrm{Cl}$ & $\mathrm{CIC} 44$ & F & 82000 & $1 b$ & 22 & Blood T & ND & ND & ND & $(-)$ & $N D$ & ND \\
\hline EUI & CIC 45 & M & - & - & - & - & $(-)$ & $(-)$ & $(-)$ & 11 & $(-)$ & $(-)$ \\
\hline $\mathrm{Cl}$ & $\mathrm{CIC} 46$ & M & 2200000 & $1 b$ & 25 & Blood T & 6(T4) & $(-)$ & 434(T8) & 10 & $(-)$ & 2070 \\
\hline EUI & $\mathrm{CIC} 47$ & $\mathrm{~F}$ & - & - & - & - & $(-)$ & $(-)$ & $(-)$ & $(-)$ & ND & ND \\
\hline $\mathrm{Cl}$ & CIC 51 & $M$ & 180000 & $2 a / c$ & 22 & Blood T & ND & ND & ND & $(-)$ & $N D$ & ND \\
\hline EUI & CIC 52 & $\mathrm{~F}$ & - & - & - & - & ND & ND & ND & $(-)$ & ND & ND \\
\hline $\mathrm{Cl}$ & $\mathrm{CIC} 60$ & M & 720000 & $1 \mathrm{a}$ & 18 & IVDU & $(-)$ & $(-)$ & 7(T8) & $(-)$ & $\mathrm{ND}$ & ND \\
\hline EUI & CIC 61 & $\mathrm{~F}$ & - & - & - & - & $(-)$, bgd & $(-)$, bgd & $(-)$, bgd & $(-)$ & ND & ND \\
\hline $\mathrm{Cl}$ & $\mathrm{CIC} 64$ & M & 1080000 & $1 b$ & ND & Unknown & $(-)$ & $(-)$ & $(-)$ & 81 & $N D$ & ND \\
\hline EUI & $\mathrm{ClC} 65$ & F & - & - & - & - & $(-)$ & $(-)$ & $(-)$ & $(-)$ & ND & ND \\
\hline
\end{tabular}

*: Chronically HCV-infected subjects (Cl); Exposed uninfected partners of chronically infected individuals (EUI).

**: Viral load expressed as LU per mL; Duration of HCV infection in years; Blood T blood transfusion, IVDU intravenous drug users.

** $(-)$ = absence, or $x x=$ presence of antigen-specific proliferation. The number $x x$ stands for specific to control antigen ration, and (T4) or (T8) for the nature of the proliferating lymphocyte population.

${ }^{* * *}(-)=$ no antigen specific ELISPOT; $x x=$ presence of antigen specific ELISPOT. The number stands for specific antigen to control ratio. Abbreviations: bgd background proliferation without antigen. ND Not determine.

The CEF panel of EBV, CMV and Flu peptides is described in ref 12. 


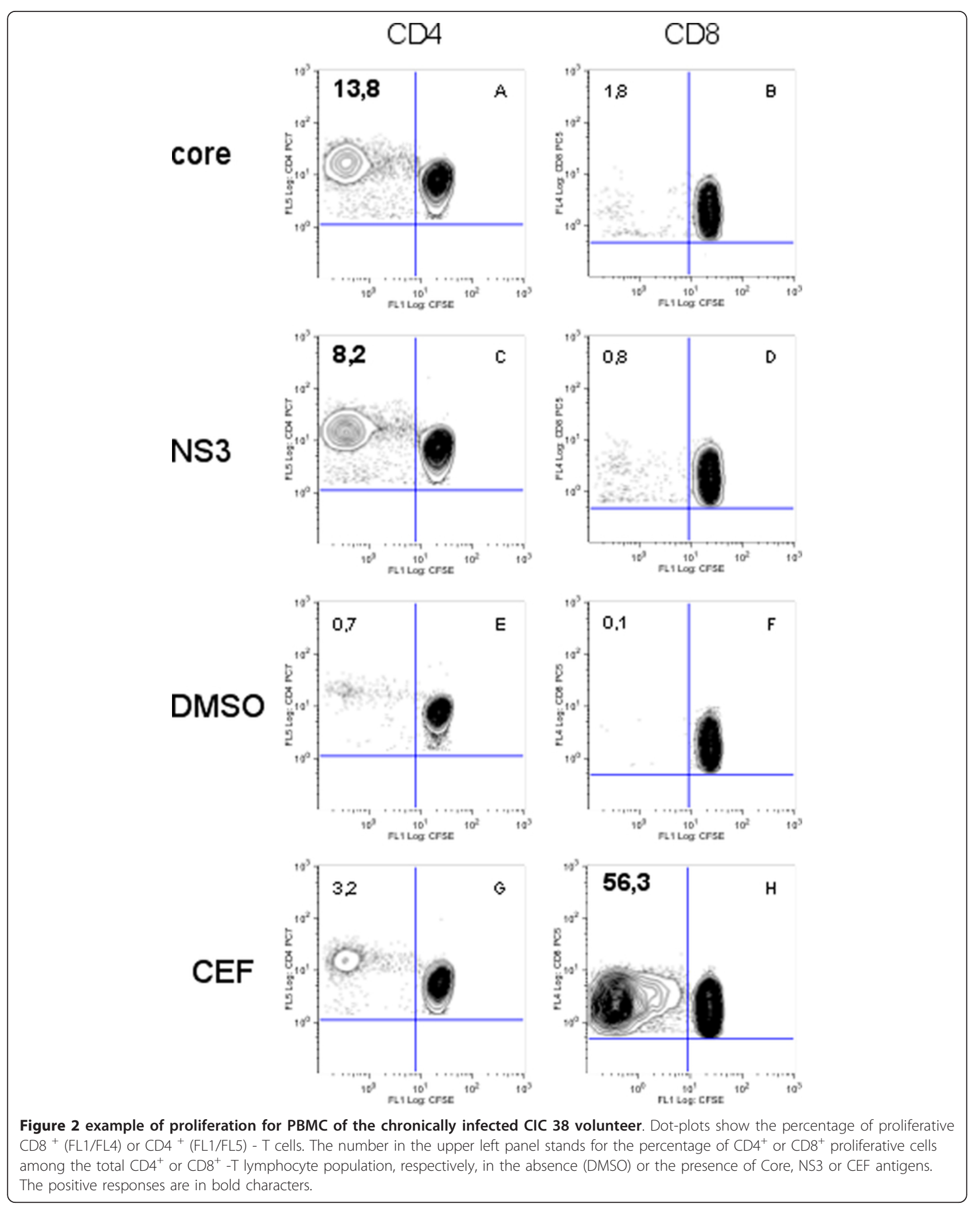


The frequencies of elispot response to Core were higher in the CI group compared to UI no risk ( $p=$ $0.04)$ and to UI at risk $(p=0.04)$. The frequencies of response to NS3 were higher in the CI group compared to UI no risk $(p<0.03)$ and to UI at risk $(p<0.03)$ (Table 1).

\section{CEF-specific responses}

EBV, CMV and Flu are viruses commonly encountered by humans. They encode peptides corresponding to CD8 class I restricted epitopes. A CEF panel of MHC class I restricted viral peptides presented by the most common Caucasian HLA types has been described [12]. CEF represents a unique peptide pool that can be used as a positive control of antigen specific $\mathrm{T}$-cell receptor-driven activation in both Elispot and proliferation assays.

Twenty-four of the 62 uninfected (UI) volunteers tested (39\%) were positive for proliferation, including $14 / 32$ volunteers at risk (44\%) and 10/30 volunteers without any known risk of exposure (33\%) (Table 1). For 23 volunteers the CEF-specific proliferation involved the CD8 population, and for 1 (EFS 12) both CD4 and CD8 populations (Tables 2 and 3). An example of CD8 response is shown in Figure 1 (panel F).

In sixteen chronically infected (CI) subjects tested, CEF-specific proliferation was detected in 56\% (9/16) individuals (Table 1). The response was detected within the CD8 lymphocyte subset only (Table 4). Proliferation profile demonstrated by volunteer CIC38 is given as an example (Figure 2, panel $\mathrm{H}$ ).

Five of the 17 (29\%) exposed uninfected (EUI) subjects (associated with the chronically infected individuals) tested were positive, the response also being solely by CD8 $\mathrm{T}$ cell population (Tables 1 and 4).

A high spontaneous background involving $\mathrm{CD} 4$ or both CD4 and CD8 subpopulations was observed for $8 / 62$ uninfected (UI), 2/16 chronically infected (CI), and 4/17 exposed but uninfected (EUI) subjects (Tables 2, 3 and 4).

In case of sufficient number of cells, CEF-specific responses were assessed also by IFN- $\gamma$ Elispot. IFN- $\gamma$ response to stimulation with CEF pool was detected in $53 \%(31 / 58)$ of uninfected (UI) volunteers, namely in $60 \%(18 / 30)$ of subjects at risk and $46 \%(13 / 28)$ individuals with no known risk of HCV exposure. Similarly, 50 and $55 \%$ response to CEF was detected respectively among chronic $\mathrm{HCV}(\mathrm{CI})$ carriers $(3 / 6)$ and their uninfected (EUI) partners (6/11; Table 1). In summary, a high proportion of individuals in each of the groups tested positive for a CEF-specific response.

No statistical difference was seen in the frequency of CEF-specific responses registered by either proliferation or Elispot (all $p$ values $>0.05$ ). This reflected similar antigen-specific $\mathrm{T}$-cell receptor driven $\mathrm{T}$ cell activation by HCV-unrelated antigens in all groups.

\section{Discussion}

We have studied three groups that differed with respect to the degree of exposition to $\mathrm{HCV}: 1)$ chronic $\mathrm{HCV}$ carrier (CI); 2) individuals who remained noninfected despite repeated exposure through sexual contact contact with these carriers (EUI); 3) healthy apparently unnexposed volunteers (UI). Specific cellular immune responses against HCV Core or NS3 were assessed by Elispot or $\mathrm{T}$ cell proliferation assays.

The highest proportion of HCV-specific response was observed among chronically-infected subjects (Table 1). The fact that such a response was detected in less than half of the patients is in agreement with previous reports on HCV T-cell responses in chronic HCV infection [13]. Elispot responses were detected the most frequently (in 8/ 20 chronically-infected volunteers tested for Core, and in $2 / 6$, tested for NS3 responses) whereas only few chronically-infected individuals presented Core or NS3-specific proliferative reactions ( $3 / 17$, and $2 / 16$, respectively).

The synthetic peptides used to screen cellular responses to $\mathrm{HCV}$ represent sequence of $\mathrm{HCV}$ genotype 1 since the majority of individuals were infected by a genotype 1 virus. Two of the three chronically-infected subjects who gave positive NS3- responses were infected with a genotype 1 virus. Seven of the eight chronicallyinfected subjects who were positive for Core by the Elispot assay, were also infected by HCV genotype 1 . Meanwhile, chronically-infected patients carried also $\mathrm{HCV}$ of three other genotypes: one was infected by a genotype 2 virus, and two by each of genotypes 3 and 4 (Table 4). Very low frequency of NS3-responders amongst patients infected with HCV genotype 2, 3 or 4, may reflect a limited number of non-HCV genotype 1 infected individuals included in this study and also the genotype variation of NS3 sequence. The latter explanation is, however, hardly applicable for the core-specific responses, since $\mathrm{HCV}$ core is highly conserved with very few amino acid inter-genotype differences [14].

The low frequency of proliferative responses compared to Elispot could be attributed to a higher sensitivity of the latter (assay). However, in our view, decisive is the type of the registered response. Elispot assays performed with $e x$ vivo isolated PBMC preferentially detect effector lymphocytes that do not need to expand, while assays using in vitro expanded $\mathrm{T}$ lymphocytes rather detect precursors of memory $\mathrm{T}$ cells with a proliferative capacity [15]. The low frequency of proliferative responses among chronic $\mathrm{HCV}$ carriers may rather reflect a weak $\mathrm{HCV}$ memory response (specifically when comparing chronic hepatitis $\mathrm{C}$ patients to those resolving $\mathrm{HCV}$ infection; for review, 13). Of particular note, relatively few individuals gave a concomitant positive response in both assays. This absence of correlation between Elispot and proliferative responses in chronically-infected individuals suggests that effector and 
memory $\mathrm{T}$ cells are distinct $\mathrm{T}$ cell populations, probably recognizing different epitopes. Such phenomenon was described earlier [16].

Interestingly, $\mathrm{HCV}$ Core-specific Elispot responses were observed in a relatively high proportion $(30 \%)$ of the uninfected partners of chronically-infected individuals (Table 1). This is in agreement with previous reports on the populations of uninfected seronegative individuals exposed to $\mathrm{HCV}$, including healthy relatives of HCV-infected individuals, intravenous drug users, and individuals with occupational exposure [17-21].

The most striking result of the current study was that despite stringent criteria of the positive cellular response, an $\mathrm{HCV}$-specific response was registered in $20 \%$ of uninfected subject tested (13/65; Tables 2 and 3). This group was split into two subgroups, depending on the possibility of exposure to $\mathrm{HCV}$. Indeed, eight individuals who displayed a positive result could have been exposed to HCV (professionally), although there was no clear history of contamination (Table 3). No such risk was, however, identified to explain positive results in the remaining five individuals (Table 2).

The detection of HCV specific cellular responses in uninfected volunteers reflects the difficulty to precisely identify all (possible) risks of exposure to HCV. Furthermore, it may also reflect a past inapparent HCV infection. Clearance of HCV viremia associated with cellular immunity in the absence of seroconversion has been reported in populations at risk for $\mathrm{HCV}$ exposure [5,22,23].

Other causes for detecting HCV-response in healthy risk-free individuals cannot be categorically ruled out. Two uninfected volunteers had positive proliferative response for Core: one with no risk of exposure to $\mathrm{HCV}$ (EFS 20) gave a response that involved both CD4 and CD8 populations, whereas the other that only implicated a CD4 population response (EFS 11) was retrospectively shown to have been exposed to HCV. For EFS 20, we could map the reactive sequence to Core amino acid residues 173190 (not shown). An extensive sequence search using the BLAST tool [24] revealed a eight amino acid homology between HCV Core 174-185 (FSIFLLALLSCL) and HBs antigen 41-52 (FIIFLFXLLXCL). While it remains possible that the observed reactivity corresponds to a cross-reactive immunization [8-10], it is noteworthy that EFS 20 was neither infected nor immunized with HBV.

NS3-specific proliferative responses were observed in four uninfected volunteers (COC 13, and EFS 14, 21 and 24). The PBMC of these individuals were also reactive to the CEF peptides including 12 influenza epitopes. As immunization against Influenza virus neuraminidase was reported to generate immune responses crossreactive with HCV NS3 [10], we cannot formally exclude that T-cell proliferation in response to NS3 resulted from cross-reactivity.
In all three groups, a much higher proportion of individuals tested positive for CEF-specific response registered by Elispot and proliferation tests. The proportion of responders (number of positive/total number tested) varied between groups, but was within the limits of stochastic variations: between $56 \%$ (9/16) for the chronically-infected subjects and 29\% (5/17) for their uninfected partners (in proliferation). These figures matched the range of proportions seen in CEF-positive Elispots: $60 \%(18 / 30)$ for at risk uninfected volunteers and $46 \%$ $(13 / 28)$ for uninfected volunteers with no known risk of $\mathrm{HCV}$-exposure (Table 1). This was somewhat lower that the data reported by Currier et al. [12], but similar to that reported by Horton et al. [25] possibly reflecting the heterogeneity of the HLA alleles in the studied groups. All CEF-specific proliferative responses involved the CD8 subpopulation, and in 1 of 95 individuals, both the CD8 and CD4 compartments. This is not surprising since most of the CEF peptides were 8 to 9 mers representing CD8 class I-restricted epitopes, although CD4-specific cytotoxic responses have also been reported in human viral infections [26-28].

As there were no statistical difference between the groups in the frequencies of proliferative or Elispot responses to the control (CEF) antigens (Table 1), exposure to or infection by $\mathrm{HCV}$ did not seem to have any major impact on the frequency of cellular responses to unrelated viruses. Hence, it is unlikely that the number of positive cellular responses to $\mathrm{HCV}$ antigens could be explained by antigen stimulation(s) specific to other viral antigens. In addition, pair-wise comparisons revealed no difference in the occurrence of cellular immune response against HCV core and/or NS3 among CEF-negative versus CEF-positive individuals in any of the groups (UI with known risk, UI at risk, EUI, or CI; all $p$ values $>0.3$ ). Thus, there is no evidence demonstrating that anti-CEF cellular reactivity interfere with the detection of anti-HCV cellular responses.

Alternatively, atypical HCV-specific immune responses may be generated by the occult HCV infections of the liver [29]. Such infections have been described for patients with abnormal liver function of unknown origin, who present negative HCV PCR and Elisa results in the serum but where HCV RNA is detected in the liver [30]. However, in our study, all uninfected CIC volunteers had normal liver biology. For the twenty COC individuals, liver function was investigated using the Fibrotest [31], and all gave a normal value (not shown). Thus, it is likely that, in this study, the detection of a positive $\mathrm{HCV}$-specific cellular response did not reflect an occult HCV infection.

The polymorphism of the IL28B gene has been recently associated with both spontaneous resolution of $\mathrm{HCV}$ infection and sustained virologic response in pegylated interferon/ribavirin treated patients [32-34]; we can 
speculate that such a polymorphism may explain partially our results but this study was initiated before the first report and we are unauthorized to make a retrospective genetic study.

In summary, the detection of $\mathrm{HCV}$-specific immune responses in uninfected volunteers may reflect an underestimated prevalence of inapparent and resolving acute HCV infections. This changes our understanding of the epidemiology and the physiopathology of HCV infection. An alternative, not mutually exclusive, hypothesis is the existence of cross-reactivity between HCV antigens and other viral or common antigens present in the general population, as previously suggested by other researchers.

\section{Patients and methods}

\section{Patients and volunteers}

Sixty-five presumably unexposed and uninfected volunteers (Uninfected individuals, UI) were studied. All volunteers were negative in HCV PCR assay (ABBOTT Real Time HCV, Abbott, Rungis, France, threshold $<12$ $\mathrm{I} . \mathrm{U} / \mathrm{ml}$ ) and had a negative $\mathrm{HCV}$-specific humoral response according to a commercial Elisa assay (MONOLISA anti-HCV Plus V2, Biorad, Marnes-la-Coquette, France). This enzyme immunoassay contains $\mathrm{HCV}$ recombinant proteins expressed in $\mathrm{E}$ coli including sequences from NS3 and NS4 and from the structural core protein. All volunteers were not infected by HBV or HIV. These volunteers were categorized according to the putative risk of exposure to $\mathrm{HCV}$ [no known risk ( $\mathrm{n}=$ $33)$, Table 2; at risk $(\mathrm{n}=32)$, Table 3]. Exclusion factors for exposure to HCV [11] were: professional exposure, drug abuse, blood transfusion or injection of blood products, sexually transmitted diseases, incarceration, alcoholism, dialysis, endoscopy, acupuncture, mesotherapy, invasive cosmetic treatment, piercing, tattooing, sexual exposure, familial exposure, and hospitalization or outpatient treatment in a developing country. The 65 volunteers were recruited in three distinct centers located in the Paris area. Initialy enrolled was a group of 20 uninfected volunteers [mean age: 46 year; range: 27-65; sex ratio: 1] (Necker Clinical Investigation Center, CIC volunteers). However, it was retrospectively reported that fifteen individuals from this group might have been exposed to HCV due to their occupational status. A second group of 25 volunteers was recruited at a french blood center in Paris (Etablissement Français du Sang (EFS), Paris; EFS 01 to 25). This group comprised 8 volunteers without any known risk for exposure to $\mathrm{HCV}$ [mean age: 27.8 year; range: $18-40$; sex ratio: 0.14 ] and 17 volunteers at risk [mean age: 43.1 year; range: $21-64$; sex ratio: 0.13$]$. The third group of 20 volunteers with no known risk for exposure to HCV was recruted at the Center for clinical investigation of the Cochin Hospital,
Paris [COC 01 to 20 ; mean age: 27.4 year; range: $18-41$; sex ratio: 1.2].

Twenty chronic HCV infected carriers and their exposed uninfected sexual partners were included as positive controls for $\mathrm{HCV}$ infection and potential exposure, respectively (Table 4). Infected patients [mean age: 46 year; range: 24-66; sex ratio: 1] were all HCV seropositive and viraemic. All viruses were genotyped except for one volunteer; the HCV genotypes were: $1 \mathrm{~b}(\mathrm{n}=10)$, 1a $(\mathrm{n}=4)], 2 \mathrm{a} / \mathrm{c}(\mathrm{n}=1), 3(\mathrm{n}=2)$, and $4(\mathrm{n}=2)$. The mode of contamination was established for fifteen individuals; ten were infected by blood transfusion, one after surgery, one following a tattooing procedure, and three were intravenous drug users. The 20 exposed uninfected partners [mean age: 44 year; range: $26-63$; sex ratio: 1] were active sexual contacts ( $>2$ years) of these infected $\mathrm{HCV}$ carriers. All exposed uninfected individuals were $\mathrm{HCV}$ seronegative and HCV-RNA negative by PCR.

None of the volunteers was infected by HIV, and all had a normal blood cell count the day of harvesting PBMCs. Biomedical research was approved by the local ethics committee (RBM 01-24), and was carried out in accordance with the Helsinki Declaration.

\section{Preparation of PBMC}

PBMCs were isolated from heparinized blood as described [35]. The PBMCs were frozen at $-80^{\circ} \mathrm{C}$ in $90 \%$ fetal calf serum (D. Dutscher, Strasbourg, France) containing 10\% DMSO (Pierce, ThermoFisher, Brebières, France), and stored in liquid nitrogen until used.

\section{Synthetic peptides}

The consensus sequence of the Core protein (genotype 1a) was covered by thirty-seven 15 mer peptides that overlapped by 10 residues, as described [35]. NS3 [consensus $1 b$, aa 1027-1657] was represented by sixty-eight overlapping 15 mer peptides corresponding to regions encoding the CD4 and CD8 epitopes were used. These clusters of T4 and T8 epitopes corresponded to the following regions: aa 1072-1111 (TCVN... LVGW); 1167-1191(GPLL... GVAK); 1199-1355(SMET... TDAL); 1461-1475 (TVDF... IETT); 1531-55(TPAE... QDHL); 1576-1652(TQKA... ACMS), according to the Los Alamos databases [36,37]. A pool of unrelated 12-to 15-mer peptides derived from Gag and Nef of simian immunodeficiency virus (SIVmac239) were used as a negative control. Core and SIV peptides were purchased from NeoMPS (Strasbourg, France), and NS3 ones from Proimmune (Oxford, UK). Each peptide was certified to be $>80 \%$ pure, by RP-HPLC. Positive control was a pool of 32 peptides (CEF) corresponding to well-characterized CD8 class I restricted epitopes of human cytomegalovirus (CMV), Epstein-Barr virus (EBV) and Influenza virus [12]. CEF pool was obtained through the NIH AIDS Research and reference reagent program, or Anaspec Inc., San Jose, CA, USA. The peptides were 
dissolved in DMSO at $1 \mathrm{mg} / \mathrm{ml}$, and were stored at $-80^{\circ} \mathrm{C}$ until used.

\section{Immunological assays}

Virus-specific circulating effector $\mathrm{T}$ lymphocyte responses were studied using two distinct functional assays:

Elispot assay $\mathrm{HCV}$-specific T cell responses of freshly isolated or frozen PBMC were studied by ex vivo ELISPOT assays [38], using the panels of Core or NS3 peptides described above. Peptides were used at a final concentration of $1 \mu \mathrm{g} / \mathrm{ml}$. Negative controls consisted of cells incubated in medium. Phorbol myristate acetate and ionomycin (25 and $100 \mathrm{ng} / \mathrm{ml}$, respectively; Sigma-Aldrich Chimie, Saint-Quentin Fallavier, France) were used as positive controls. The frequencies of IFN $-\gamma$ producing cells were expressed as the number of spot-forming cells (SFC) per $10^{6}$ cells. Frequencies lower than 50 spots/l million PBMC were considered unspecific. An assay was considered positive if: $1 /$. The number of spots generated in response to stimulation with specific peptides exceeded the mean of the number of spots obtained with culture medium plus $2 \mathrm{SD}$; and $2 /$. Its ratio to the number of spots with culture medium was $>$ or $=4$.

Proliferation assay PBMC $\left(2 \times 10^{6} / \mathrm{ml}\right)$ were labelled with $10 \mathrm{mM}$ carboxyfluorescein diacetate succinimidyl ester (CFDA-SE; Invitrogen, ref C1157) in serum-free medium for $30 \mathrm{~min}$ at $37^{\circ} \mathrm{C}$ [39]. Labeled PBMC were washed with complete medium (D-MEM $+1 \%$ non essential aminoacids, $1 \mathrm{mM}$ L-glutamine, Invitrogen, Cergy, France) supplemented with $10 \%$ heat inactivated human $A B$ serum (SAB, Biowest, France), and incubated in complete D-MEM culture medium at $37^{\circ} \mathrm{C}$ under $5 \% \mathrm{CO}_{2}$. The following antigen stimulations were performed: $1 /$. HCV-specific with pools of Core or NS3-specific peptides each at a final concentration of $1 \mu \mathrm{g} / \mathrm{ml} ; 2 /$. Common antigen-specific CEF peptides as positive control (final concentration $0.5 \mu \mathrm{g} / \mathrm{ml}$ ); 3/. Mitogen (superantigen) Staphylococcus Enterotoxin B (Ref S4881, Sigma, St Louis, MI) at $500 \mathrm{ng} / \mathrm{mL}$ as positive control for PBMC viability; 4/. An irrelevant SIV-peptide pool, and complete medium plus $0.05 \%$ DMSO (peptide diluent) as negative controls.

After 6 days incubation, cells were washed in PBS and incubated for $30 \mathrm{~min}$ at $25^{\circ} \mathrm{C}$ with anti CD3 phycoerythrin-Texas Red (ECD)-, anti-CD8 $\beta$ phycoerythrin-cyanin 5 (PCy5)-, and anti CD4 phycoerythrin-cyanin 7 (PCy7)conjugated monoclonal antibodies (refs A07748, 6607101, and 737660 from Beckman-Coulter respectively). At the end of the incubation period, cells were washed twice in PBS and fixed with $200 \mu \mathrm{L}$ of $2 \%$ formaldehyde solution in PBS for $15 \mathrm{~min}$ at $25^{\circ} \mathrm{C}$. Cell division accompanied by CFSE dilution [39] was analyzed by flow cytometry. For each sample, at least $10^{5}$ events were acquired using a FC500 cytometer (Beckman Coulter). Data were analysed with FlowJo (TreeStar). Lymphocytes were gated based on their forward and side scattering dot plot. T lymphocytes were defined based on their expression of CD3 and CD4 or CD8. The following criteria for antigen-specific proliferation were set: $1 /$. Background of proliferation without antigen (DMSO) $<4 \% ; 2 /$. Antigen proliferation ratio (Antigen/SIV) $>$ or $=4 . ; 3 /$. Absolute number of proliferating cells (i.e. CFSE negative) $>100 ; 4 /$. Threshold value $>$ mean of difference between control antigen (SIV) +2 SD .

\section{Statistics}

Frequencies of $\mathrm{HCV}$-specific proliferative and IFN- $\gamma$ ELISPOT responses between groups were compared between the groups pairwisely using two-sided $t$-test for independant samples assessing difference in proportions. Tests were done using Quick Calcs, Graph Pad Software.

\section{Authors' informations}

Present address for L. Durrieu: Centre de recherche CHU Ste-Justine, Département de Microbiologie et Immunologie, Université de Montréal, 3175, Chemin de la Côte-Sainte-Catherine, Montréal H3T 1C5 Québec, Canada.

Corresponding author contact information: Yves Rivière, Viral Immunopathology URA CNRS 3015, Department of Virology, Lwoff Building, Institut Pasteur, 28 rue du Dr Roux, 75015 Paris. tel 3314568 8778; fax 331 4061 3298; yves.riviere@pasteur.fr or yves.l.riviere@gmail.com.

\section{Abbreviations \\ EUI: Exposed Uninfected Individuals; UI: Uninfected Individuals; $\mathrm{Cl}$ : Chronically Infected Individuals.}

\section{Acknowledgements}

This research has been supported in part by grant from l'Agence Nationale de Recherches sur le SIDA et les hépatites virales, from INSERM, Aventis and Institut Pasteur. The authors thank the study participants and all participating clinicians at each site (CIC BT505: Linda Bélarbi, Pierre Loulergue, Diane van der Vliet; CIC Necker : Agnès Mogenet; EFS : Benoît Mercier, Djamel Benhomar). We are grateful to Marie-Louise Michel, Florence Buseyne and Daniel Scott-Algara, Institut Pasteur, and Michael McChesney, UC Davis, CA, for discussions, and Bertrand Saunier, INSERM, Hôpital Cochin for critical analysis of the results. We also acknowledge proof reading of the manuscript by Katherine M. Kean.

\section{Author details}

'Laboratoire d'Immunopathologie Virale, Institut Pasteur; and CNRS URA 3015, 25 rue du Dr Roux, 75015 Paris, France. ²EA 3620, Université ParisDescartes; and Laboratoire de Virologie, CHU Necker-Enfants Malades, AP-HP, Paris, France. ${ }^{3}$ Institute for Microbiology, Tumor and Cell Biology, Karolinska Institutet, 17177 Stockholm, Sweden. ${ }^{4}$ Université Paris-Descartes; AP-HP, Hôpital Cochin, CIC de Vaccinologie Cochin-Pasteur Inserm CIC BT505, Paris, France. ${ }^{5}$ Centre d'investigation clinique, Hôpital Necker-Enfants Malades, Université Descartes, Paris, France. ${ }^{6}$ Unité d'Hépatologie, Hôpital Cochin, APHP; INSERM U1016; and Université Paris-Descartes, Paris, France.

\section{Authors' contributions}

TM, GJ, CM, LD carried out the elispot and proliferation assays. MLC carried out the virological assays. MLC, OL, JLB, SP participated in the design of the study and were responsible for the clinical data from volunteers. MI, TM ad 
JLB participated in the statistical analysis. YR was responsible for the design and coordination of the study, and for the writting of the manuscript. All authors read and approved the final manuscript.

\section{Competing interests}

The authors have no competing interests with any commercial or other association in conjunction with the research presented herein.

Received: 21 September 2011 Accepted: 28 March 2012 Published: 28 March 2012

\section{References}

1. Allain JP: Hepatitis C virus in blood donation. Lancet 2005, 365:276-278.

2. Semmo N, Barnes E, Taylor C, Kurtz K, Harcourt G, Smith N, et al: T-cell responses and previous exposure to hepatitis $C$ virus in indeterminate blood donors. Lancet 2005, 365:327-329.

3. Meyer MF, Lehmann M, Cornberg M, Wiegand J, Manns MP, Klade C, et al: Clearance of low levels of HCV viremia in the absence of a strong adaptive immune response. Virol J 2007, 4(58):1-11.

4. Takaki A, Wiese M, Maertens G, Depla E, Seifert U, Liebetrau A, et al: Cellular immune responses persist and humoral responses decrease two decades after recovery from a single-source outbreak of hepatitis $C$. Nature medicine 2000, 6:578-582.

5. Widell A, Busch M: Exposed or not exposed-that is the question: evidence for resolving and abortive hepatitis $\mathrm{C}$ virus infections in blood donors. Transfusion 2009, 49:1277-1281.

6. Post JJ, Ratnarajah S, Llyod AR: Immunological determinants of the outcomes from primary hepatitis C infection. Cell Mol Life Sci 2009, 66:733-756.

7. Kamal SM, Amin A, Madwar M, Graham CS, He Q, Al Tawil A, et al: Cellular immune responses in seronegative sexual contacts of acute hepatitis $C$ patients. J Virol 2004, 78:11252-11258.

8. Kammer AR, van der Burg SH, Grabscheid B, Hunziker IP, Kwappenberg KMC, Reichen J, et al: Molecular mimicry of human cytochrome P450 by hepatitis $C$ virus at the level of cytotoxic T cell recognition. J Exp Med 1999, 190:169-176.

9. Wedemeyer H, Mizukoshi E, Davis AR, Bennink JR, Rehermann B: Crossreactivity between hepatitis $C$ virus and Influenza $A$ virus determinantspecific cytotoxic T cells. J Virol 2001, 75:11392-11400.

10. Kennedy PT, Urbani S, Moses RA, Amadei B, Fisicaro P, Lloyd J, et al: The influence of T cell cross-reactivity on HCV-peptide specific human T cell response. Hepatology 2006, 43:602-611.

11. Karmochkine M, Carrat F, Dos Santos O, Cacoub P, Raguin G: for the GERMIVIC Study Group. A case-control study of risk factors for hepatitis C infection in patients with unexplained routes of infection. J Viral Hepatitis 2006, 13:775-782.

12. Currier JR, Kuta EG, Turk E, Earhart LB, Loomis-Price L, Janetzki S, et al: A panel of MHC class I restricted viral peptides for use as a quality control for vaccine trial ELISPOT assays. J Immunol Methods 2002, 260:157-172.

13. Thimme R, Neumann-Haefelin C, Boettler T, Blum HB: Adaptive immune responses to hepatitis $C$ virus: from viral immunobiology to a vaccine. Biol Chem 2008, 389:457-467.

14. Yusim K, Richardson R, Tao N, Szinger JJ, Funkhouser R, Korber B, et al: HCV HCV immunology database: the Los Alamos Hepatitis C Immunology Database. Appl Bioinforma 2005, 4:217-225.

15. Sallusto F, Lenig D, Forster R, Lipp M, Lanzavecchia A: Two subsets of memory T lymphocytes with distinct homing potentials and effector functions. Nature 1999, 401:708-712.

16. McKinnon LR, Blake Ball T, Wachihi C, McLaren PJ, Waruk JLM, Mao X, et al: Epitope cross-reactivity frequently differs between central and effector memory HIV-specific CD8-T cells. J Immunol 2007, 178:3750-3756.

17. Bronowicki JP, Vetter $\mathrm{D}$, Uhl G, Hudziak $\mathrm{H}$, Uhrlacher A, Vetter JM, et al: Lymphocyte reactivity to hepatitis $\mathrm{C}$ virus (HCV) antigens shows evidence for exposure to HCV in HCVseronegatives spouses of HCVinfected patients. J Infect Dis 1997, 176:518-527.

18. Jackson M, Smith B, Bevitt DJ, Steward M, Toms GL, Bassendine MF, et al: Comparison of cytotoxic T lymphocyte responses to Hepatitis $C$ virus core protein in uninfected and infected individuals. J Med Virol 1999, 58:239-246.
19. Koziel MJ, Wong DK, Dudley D, Houghton M, Walker BD: Hepatitis C virusspecific cytolytic $\mathrm{T}$ lymphocyte and $\mathrm{T}$ helper responses in seronegative persons. J Infect Dis 1997, 176:859-867.

20. Scognamiglio P, Accapezzato D, Casciaro MA, Cacciani A, Artini M, Bruno G, et al: Presence of effector CD8+ T cells in Hepatitis $C$ virus exposed healthy seronegative donors. J Immunol 1999, 162:6681-6689.

21. Zeremski M, Shu MA, Brown Q, Wu Y, Des Jarlais DC, Busch MP, et al: Hepatitis C virus-specific T-cell immune responses in seronegative injection drug users. J Viral Hepat 2009, 16:10-20.

22. Post JJ, Pan Y, Freeman AJ, Harvey CE, White PA, Palladinetti P, et al: Clearance of hepatitis $C$ viremia associated with cellular in the absence of seroconversion in the hepatitis $\mathrm{C}$ incidence and transmission in prisons study cohort. J Infect Dis 2004, 189:1846-1855.

23. Hashem M, El-Karksy H, Shata MT, Sobhy M, Helmy H, El-Naghi S, et al Strong Hepatitis C Virus (HCV)-specific cell-mediated immune responses in the absence of viremia or antibodies among uninfected siblings of HCV chronically infected children. J Infect Dis 2011, 203:854-861.

24. Altschul SF, Madden TM, Schäffer AA, Zhang J, Zhang Z, Miller W, et al: Gapped BLAST and PSI-BLAST: a new generation of protein database search programs. Nucleic Acids Res 1997, 25:3389-3402.

25. Horton H, Russell N, Moore E, Frank I, Baydo R, Havenar-Daughton C, et al: Correlation between Interferon- $\gamma$ Secretion and Cytotoxicity in VirusSpecific Memory T Cells. J Infect Dis 2004, 190:1692-1696.

26. Littaua RA, Oldstone MBA, Atakeda A, Ennis FA: A CD4+ Cytotoxic TLymphocyte Clone to a Conserved Epitope on Human Immunodeficiency Virus Type 1 p24: Cytotoxic Activity and Secretion of Interleukin-2 and Interleukin-6. J Virol 1992, 66:608-611.

27. Demkowicz WE Jr, Littaua RA, Wang J, Ennis FA: Human Cytotoxic T-Cell Memory: Long-Lived Responses to Vaccinia Virus. J Virol 1996, 70:2627-2631.

28. Puissant-Lubrano B, Bossi P, Gay F, Crance JM, Bonduelle O, Garin D, et al: + effector/memory CD4+ lymphocytes in humans + TNF-a Control of vaccinia virus skin lesions by long-term-maintained IFN-g. J Clin Invest 2010, 120:1636-1644.

29. Quiroga JA, Llorente S, Castillo I, Rodriguez-Inigo E, Pardo M, Carreno V: Cellular immune responses associated with occult hepatitis $C$ virus infection in the liver. J Virol 2006, 80:10972-10979.

30. Castillo I, Pardo M, Bartolomé J, Ortiz-Movilla N, Rodriguez-Inigo E, de Lucas $S$, et al: Occult hepatitis $C$ infection in patients in whom the etiology of persistently abnormal results of liver-function tests is unknown. J Infect Dis 2004, 189:7-14

31. Poynard $T$, Lebray $P$, Ingiliz $P$, Varaut $A$, Ngo $Y$, Norha $P$, et al: Prevalence of liver fibrosis and risk factors in a general population usng non-invasive biomarkers (Fibrotest). BMC Gastroenterol 2010, 10:4.

32. Ge D, Fellay J, Thompson AJ, Simon JS, Shianna KV, Urban TJ, Heinzen EL, Qiu P, Bertelsen AH, Muir AJ, Sulkowski M, McHutchison JG, Goldstein DB: Genetic variation in IL28B predicts hepatitis $C$ treatment-induced viral clearance. Nature 2009, 461:369-401.

33. Thomas DL, Chloe L, Thio CL, Maureen P, Martin MP, Qi Y, Dongliang Ge D, O'hUigin C, Kidd J, Kidd K, Khakoo SI, Alexander G, Goedert JJ, Kirk GD, Sharyne M, Donfield SM, Rosen HR, Tobler LH, Busch MP, McHutchison JG, Goldstein DB, Carrington Mary: Genetic variation in IL28B and spontaneous clearance of hepatitis C virus. Nature 2009, 461:798-802.

34. Jensen DM, Pol S: IL28B genetic polymorphism testing in the era of direct acting antivirals therapy for chronic hepatitis C: ten years too late? Liver Int 2012, 32:74-78.

35. Janvier G, Chaix ML, Fontaine $H$, Bresson $J L$, Pol S, Rivière $Y$ : The corespecific precursor $\mathrm{T}$ cell response is directed to the $\mathrm{N}$-terminal and central parts of the protein and positively correlates to the viral load in chronically HCV-infected patients. Virology 2005, 340:318-325.

36. Kuiken C, Mizokami M, Deleage G, Yusim K, Penin F, Shin-I T, et al: Hepatitis C Databases, Principles and Utility to Researchers. Hepatology 2006, 143:1157-1165.

37. Kuiken C, Yusim K, Boykin L, Richardson R: The Los Alamos hepatitis C sequence database. Bioinformatics 2005, 21:379-384.

38. Buseyne F, Catteau A, Scott-Algara D, Corre B, Porrot F, Rouzioux C, et al: A Vaccinia-based Elispot assay for detection of CD8+ T cells from HIV-1 infected children. J Immunol Methods 2005, 298:105-118. 
39. Lyons AB: Analysing cell division in vivo and in vitro using flow cytometric measurement of CFSE dye dilution. J Immunol Methods 2000 243:147-154.

doi:10.1186/1743-422X-9-76

Cite this article as: Rivière et al:: Hepatitis C virus-specific cellular immune responses in individuals with no evidence of infection. Virology Journal 2012 9:76.

Submit your next manuscript to BioMed Central and take full advantage of:

- Convenient online submission

- Thorough peer review

- No space constraints or color figure charges

- Immediate publication on acceptance

- Inclusion in PubMed, CAS, Scopus and Google Scholar

- Research which is freely available for redistribution

Submit your manuscript at www.biomedcentral.com/submit

() BioMed Central 